\title{
Analisis Teknikal Return Saham dengan Indikator-Indikator Bollinger Band, Parabolic SAR, dan Stochastic Oscillator
}

\section{Technical Analysis of Stock Returns with Bollinger Band, Parabolic SAR, and Stochastic Oscillator Indicators}

\author{
Ikhza Syafa Muis ${ }^{1)}$, Maretha Ika Prajawati ${ }^{2)}$, Basir $\mathbf{S}^{3)}$ \\ ${ }^{1,2)}$ Fakultas Ekonomi, UIN Maulana Malik Ibrahim, Kota Malang \\ ${ }^{3)}$ Sekolah Kajian Stratejik dan Global, Universitas Indonesia, Jakarta Pusat \\ e-mail korespondensi: Ikhza25@gmail.com
}

\begin{tabular}{|c|c|}
\hline Info & $\mathbf{A b}$ \\
\hline $\begin{array}{l}\text { Riwayat Artikel: } \\
\text { Diterima: } 08 \text { Juli } 2020 \\
\text { Disetujui: } 09 \text { September } 2020 \\
\text { Dipublikasikan: Juli } 2021\end{array}$ & $\begin{array}{l}\text { Dalam mengambil keputusan dalam membeli saham di pasar modal, seorang } \\
\text { investor harus mengetahui metode analisis yang ada di dalam investasi saham. } \\
\text { Salah satu metode yang digunakan adalah analisis teknikal. Penelitian ini } \\
\text { bertujuan untuk mengetahui perbandingan return saham yang dihasilkan }\end{array}$ \\
\hline $\begin{array}{l}\text { Nomor DOI } \\
\text { 10.33059/jseb.v12i2.2467 } \\
\text { Cara Mensitasi : } \\
\text { Muis, I. S., Prajawati, M. I., \& } \\
\text { Basir S. (2021). Analisis } \\
\text { teknikal return saham dengan } \\
\text { indikator-indikator Bollinger } \\
\text { band, parabolic SAR, dan } \\
\text { stochastic oscillator. Jurnal } \\
\text { Samudra Ekonomi dan Bisnis, } \\
\text { 12(2), 143-153. doi: } \\
\text { 10.33059/jseb.v12i2.2467. }\end{array}$ & $\begin{array}{l}\text { menggunakan indikator-indikator Bollinger Band, Parabolic SAR, dan Stochastic } \\
\text { Oscillator. Jenis penelitian ini adalah pendekatan kuantitatif dengan metode } \\
\text { komparatif. Teknik pengambilan sampel menggunakan purposive sampling, } \\
\text { sehingga diperoleh } 14 \text { perusahaan. Hasil penelitian menunjukkan indikator- } \\
\text { indikator Bollinger Band, Parabolic SAR, dan Stochastic Oscillator dapat } \\
\text { dijadikan pedoman dalam menentukan jual-beli saham untuk mendapatkan } \\
\text { return yang optimal. } \\
\text { Kata Kunci: Analisis Teknikal, Bollinger Band, Parabolic SAR, Stochastic } \\
\text { Oscillator, Return Saham. }\end{array}$ \\
\hline
\end{tabular}

\begin{tabular}{|c|c|}
\hline Article Info & Abstract \\
\hline $\begin{array}{l}\text { Article History: } \\
\text { Received: } 08 \text { July } 2020 \\
\text { Accepted: } 09 \text { September } 2020 \\
\text { Published: July } 2021\end{array}$ & $\begin{array}{l}\text { In making a decision to buy shares in the stock market, an investor must know } \\
\text { the analytical methods involved in stock investing. One of the methods used is } \\
\text { technical analysis. This study aims to determine the comparison of stock returns } \\
\text { generated using the Bollinger Band, Parabolic SAR, and Stochastic Oscillator }\end{array}$ \\
\hline $\begin{array}{l}\text { DOI Number: } \\
\text { 10.33059/jseb.v12i2.2467 } \\
\text { How to cite : } \\
\text { Muis, I. S., Prajawati, M. I., \& } \\
\text { Basir S. (2021). Analisis } \\
\text { teknikal return saham dengan } \\
\text { indikator-indikator Bollinger } \\
\text { band, parabolic SAR, dan } \\
\text { stochastic oscillator. Jurnal } \\
\text { Samudra Ekonomi dan Bisnis, } \\
\text { 12(2), 143-153. doi: } \\
\text { 10.33059/jseb.v12i2.2467. }\end{array}$ & $\begin{array}{l}\text { indicators. This type of research is a quantitative approach with a comparative } \\
\text { method. The sampling technique used purposive sampling, in order to obtain } 14 \\
\text { companies. The results show that the indicators of Bollinger Band, Parabolic } \\
\text { SAR, and Stochastic Oscillator can be used as guidelines in determining the } \\
\text { buying and selling of stocks to get optimal returns. } \\
\text { Keywords: Technical Analysis, Bollinger Band, Parabolic SAR, Stochastic } \\
\text { Oscillator, Stock Return. }\end{array}$ \\
\hline
\end{tabular}




\section{PENDAHULUAN}

Pasar modal merupakan kegiatan yang berkaitan dengan perdagangan efek atau penawaran umum dari perusahaan yang akan go-public serta dapat juga dikatakan sebagai wadah bagi investor dan pihak ketiga yang membutuhkan dana besar untuk melakukan jual-beli atau perdagangan instrumen pasar modal (Rahardjo, 2006). Pasar modal dari tahun ke tahun terobservasi terus mengalami perkembangan yang pesat di Indonesia. Hal ini terlihat dari total investor di Pasar Modal Indonesia yang tercatat di PT. Kustodian Sentral Efek Indonesia (KSEI) sebagai Single Investor Identification (SID) mencapai 2,47 juta SID per Desember 2019. Angka ini menunjukan kenaikan sebesar 53 persen dibandingkan periode Desember 2018 yang tercatat sebanyak 1,62 juta SID. Dari keseluruhan total investor 44,62 persen adalah investor milenial atau lebih muda dari 30 tahun. Dalam pengelompokkan ini, aset terdaftar dari investor milenial mencapai Rp. 12,42 triliun (Artanti, 2019).

Dengan adanya media pasar modal, masyarakat berpenghasilan kecil mempunyai kesempatan untuk mengembangkan uang mereka dengan berinvestasi pada perusahaan yang terdaftar di pasar modal atau membeli sebagian kecil saham perusahaan publik. Apabila sebagian kecil saham tersebut terus berkembang dan meningkat jumlahnya, maka terdapat kemungkinan bisa menjadi pemilik saham mayoritas.

Sebelum mengambil keputusan dalam membeli saham di pasar modal, seorang investor harus mengetahui metode analisis yang ada di dalam investasi saham. Terdapat dua metode analisis investasi saham, yaitu analisis fundamental dan analisis teknikal. Analisis fundamental yaitu analisis saham untuk mengetahui nilai sebenarnya dari suatu aset finansial yang berasal dari laporan keuangan perusahaan; sedangkan analisis teknikal adalah teknik menganalisis naik turunnya harga dalam jangka waktu tertentu atau berhubungan dengan faktor lain seperti volume transaksi. Oleh karena itu, analisis teknikal banyak menggunakan grafik. Dari pergerakan tersebut akan terlihat pola tertentu yang dapat dipakai sebagai dasar untuk melakukan pembelian maupun penjualan saham. Biasanya analisis fundamental banyak digunakan oleh investor jangka panjang, sedangkan analisis teknikal banyak digunakan investor jangka pendek maupun menengah.

Dalam penelitian ini digunakan analisis teknikal untuk membantu proses analisis saham. Analisis teknikal yang dipakai dalam penelitian ini adalah indikator-indikator Bollinger Bands yang ditemukan oleh John Bollinger pada tahun 1980-an, Parabolic SAR oleh J. Welles Wilder pada tahun 1978-an, dan Stochastic Oscillators oleh George C. Lane pada tahun 1950-an.

Dalam pemilihan ketiga indikator itu dikarenakan terdapat penelitian terdahulu yang meneliti penggunaan indikator tersebut, sehingga peneliti ingin membuktikan kebenaran hasil penelitian tersebut. Indikatorindikator tersebut juga memiliki kelebihan diantaranya Bollinger Bands yang memiliki kelebihan berupa kemampuan mendeteksi berakhirnya suatu trend, dapat digunakan untuk melihat pergantian momentum. Parabolic SAR memiliki kelebihan yaitu cukup ampuh ketika market mengalami trend kuat, menginformasikan bahwa pasar sedang trending dan memberitahu adanya indikasiindikasi pembalikan arah harga. Stochastic Oscillator memiliki kelebihan yaitu mampu memberikan sinyal lebih dini.

Penelitian terdahulu yang mendukung mengenai penggunaan indikator-indikator Bollinger Band, Parabolic SAR, Stochastic Oscillaor yaitu: Frankandinata \& Cahyadi (2014) yang meneliti indikator Bollinger Bands terhadap pergerakan harga saham 
saham AALI; Marli \& Deccasari (2014) yang meneliti Bollinger Band dalam transaksi short time perdagangan saham; Srichawla \& Romprasert (2017) yang meneliti efektifitas indikator konfirmasi pada saham di Bursa Thailand dengan enam indikator; Sulthon et al. (2018) yang meneliti mengenai Parabolic SAR sebagai indikator tambahan; Prabatha (2012) yang meneliti Stochatic Oscillator dan MACD pada saham-saham JII; M'ng \& Mehralizadeh (2016) yang meneliti mengenai Bollinger Band dan Stochastic Oscillator di pasar berjangka; serta, Prasetyo et al. (2019) yang meneliti penggunaan metode-metode Stochastic Oscillator, MA, dan MACD.

Penelitian-penelitian yang berargumen bahwa indikator-indikator Bollinger Band, Parabolic SAR, Stochastic Oscillator tidak menguntungkan diantaranya oleh Suryawan \& Bagiarta (2017) yang meneliti strategi Bolinger Band, MA, dan RSI pair AUD/USD dan EUR/USD; How et al. (2015) yang meneliti Candlestick dan Parabolic SAR pada komoditas emas; serta, Suryawan (2016) yang meneliti kombinasi Stochastic dan Linier Weighted Moving Average di pasar forex. Berdasarkan latar belakang yang telah diuraikan, dinilai sangat menarik untuk melakukan penelitian mengenai penggunaan analisis teknikal dalam menilai return saham.

\section{Investasi}

Investasi merupakan penanaman modal yang biasanya berjangka waktu lama dengan harapan mendapatkan keuntungan di masa mendatang. Dengan demikian bisa dinyatakan bahwa investasi merupakan komitmen atas penanaman modal atau sejumlah dana dengan harapan mendapatkan keuntungan masa yang akan datang (Sunariyah, 2006). Tujuan investasi adalah untuk mendapatkan sejumlah pendapatan keuntungan di masa yang akan datang. Menurut Tandelilin (2001), terdapat berbagai macam alasan mengapa seseorang melakukan kegiatan investasi, antara lain adalah untuk mendapatkan kehidupan yang lebih layak di masa depan, mengurangi imbas dari inflasi, sebagai usaha menghemat pajak.

\section{Analisis Teknikal}

Menurut Hendarto (2005), analisis teknikal adalah analisis yang memakai pengujian pergerakan harga di masa lampau untuk bertujuan memprediksikan (forecast) pergerakan harga di masa mendatang. Analisis teknikal dapat dipakai untuk melakukan forecast antara lain pada valuta asing (forex), saham (stock), opsi (option), ataupun instrumen-instrumen yang dapat diperjual-belikan di pasar keuangan.

\section{Bollinger Band}

Indikator yang ditemukan oleh John Bollinger pada tahun 1980-an merupakan pengembangan MA atau Moving Average menjadi dua garis, yaitu garis atas atau upper bands, dan garis bawah atau lower bands. Apabila pergerakan harga berada di luar upper bands maka mengkonfirmasikan bahwa kondisi harga sedang jenuh beli atau overbought. Sebaliknya, apabila harga berada di luar lower band akan mengkonfirmasikan bahwa kondisi sedang mengalami jenuh jual atau oversold.

Untuk rekomendasi setting standar oleh John Bollinger yaitu 20 - 2. Angka ini berarti menggunakan MA-20 dengan 2 Standar Deviasi. Garis upper band adalah hasil dari MA-20 ditambahkan 2 Standar Deviasi; sedangkan garis lower band adalah hasil dari MA-20 dikurangi 2 Standar Deviasi. Deviasi adalah istilah yang digunakan untuk menampilkan volatilitas atas suatu saham (Ong, 2016).

\section{Parabolic SAR}

Parabolic SAR merupakan indikator ini ditemukan oleh J. Welles Wilder tahun 1978. 
Indikator ini dinilai cukup baik ketika pergerakan harga mengalami trend kuat, sebaliknya indikator ini dianggap kurang sesuai bagi market dalam kondisi sideways; sehingga indikator ini bisa dikatakan sebagai bagian dari trend following indicators. Kata "SAR" pada indikator ini merupakan komparasi antara waktu dan harga yang berasal dari kata "Stop and Reverse". Di sisi lain, kata "Parabolic" digunakan untuk mengilustrasikan garis Parabolic SAR yang berpola seperti bentuk parabola (Ong, 2016).

\section{Stochastic Oscillator}

Indikator Stochastic ditemukan oleh George C. Lane. Indikator ini menampakkan dua garis dalam oscillator yang disebut dengan garis $\% \mathrm{D}$ dan $\% \mathrm{~K}$. Kedua garis ini berkisar antara skala 0-100. Di level $80 \mathrm{ke}$ atas disebut dengan zona overbought (jenuh beli), dan di level 20 ke bawah disebut dengan zona oversold (jenuh jual). Garis $\% \mathrm{~K}$ adalah garis utama dan disebut dengan signal line. Sedangkan garis \%D adalah moving average dari garis $\% \mathrm{~K}$ dan disebut dengan trigger line. Sinyal beli apabila garis \% $\mathrm{K}$ memotong ke atas garis $\% \mathrm{D}$ dan berada di zona oversold; sementara sinyal jual apabila garis $\% \mathrm{~K}$ memotong ke bawah garis \%D dan berada di zona overbought (Ong, 2016).

\section{Return Saham}

Return saham merupakan perolehan yang dijelaskan dari presentase modal awal investasi. Perolehan investasi dalam saham meliputi profit dari jual beli saham, yang mana apabila profit disebut dengan capital gain dan apabila rugi disebut capital loss. Di sisi lain, investor juga bisa mendapatkan dividen setiap tahunnya dari perusahaan. Pada penelitian ini, return saham yang digunakan yaitu menghitung capital gain (atau loss) dengan grafik harga saham harian. Untuk menghitung return saham dapat dilakukan menggunakan rumus (Samsul, 2006):

$$
R=\frac{P_{t}-P_{t-1}}{P_{t-1}}
$$

dimana $R$ adalah return saham $i$ untuk waktu $t ; P_{t}$ adalah harga untuk waktu $t$; dan, $P_{t-1}$ adalah harga untuk waktu sebelumnya.

\section{METODE PENELITIAN}

Jenis penelitian yang digunakan ialah penelitian kuantitatif dengan metode komparatif. Menurut Suryani \& Hendryadi (2016), penelitian komparatif bertujuan untuk membandingkan satu atau lebih data sampel. Penggunaan metode komparatif digunakan untuk membandingkan antara indikatorindikator Bollinger Band, Parabolic Sar dan Stochastic Oscillator dalam menganalisis return saham.

Populasi yang digunakan adalah seluruh perusahaan yang tergolong dalam sektor infrastruktur, utilitas, dan transportasi pada Bursa Efek Indonesia periode 2017-2019. Sampel diseleksi menggunakan purposive sampling, yaitu teknik pengambilan sampel dengan mempertimbangkan kriteria tertentu sehingga memudahkan peneliti menjelajahi objek yang diteliti (Sugiyono, 2016). Teknik pengambilan sampel sumber data dengan kriteria tertentu dalam memilih sampelnya, sehingga didapatkan 14 perusahaan sektor infrastruktur, utilitas, dan transportasi dari total keseluruhan. Prosedur pemilihan sampel dapat ditunjukkan pada Tabel 1.

\section{Metode Analisis Data}

Data penelitian diinput melalui grafik pergerakan harga saham harian dengan menggunakan software Chartnexus version 5 pada sektor infrastruktur, utilitas, dan transportasi periode 2017-2019. 
Tabel 1. Pemilihan Sampel

\begin{tabular}{clc}
\hline No & \multicolumn{1}{c}{ Keterangan } & Jumlah \\
\hline 1 & $\begin{array}{l}\text { Perusahaan yang terdaftar kedalam sektor infrastruktur, utilitas, dan } \\
\text { transportasi selama periode } 2017-2019\end{array}$ & 53 \\
2 & $\begin{array}{l}\text { Perusahaan yang pergerakan grafik sahamnya tidak mengalami bullish } \\
\text { maupun bearish (saham yang tidak ada pergerakan dalam waktu yang } \\
\text { lama, sedikit peminat, dan sudah mencapai harga batas bawah) } \\
\text { Perusahaan yang pasif sahamnya dalam transaksi secara berkelanjutan } \\
\text { serta mendapatkan suspend dari Bursa Efek Indonesia selama periode } \\
\text { 2017-2019 }\end{array}$ & \multicolumn{1}{c}{ Jumlah Sampel } \\
\hline
\end{tabular}

Sumber: Diolah penulis, 2020.

Pergerakan grafik harga saham tersebut dianalisis menggunakan indikator-indikator teknikal berupa Bollinger Band, Parabolic SAR, dan Stochastic Oscillator sebagai penentu kapan waktunya beli dan jual untuk melihat return yang didapat selama kurun waktu 2017-2019. Proses input data dibantu program SPSS 21 yang dilakukan via offline.

Uji normalitas digunakan untuk tujuan mengetahui apakah data tersebut berdistribusi normal atau tidak. Pengujian ini dilakukan memakai Shapiro-Wilk. Kriteria pengambilan keputusan yang digunakan bahwa apabila nilai Asymp. Sig. (2-tailed) lebih besar dari 0,05 berarti data penelitian ini berdistribusi normal; sebaliknya apabila nilai Sig. lebih kecil dari 0,05 berarti data penelitian ini berdistribusi tidak normal (Santoso, 2015).

Selanjutnya, dilakukan uji ANOVA (Analysis of Variance) yang ditujukan untuk menguji rata-rata perbedaan atas return saham berdasarkan ketiga indikator yang dianalisis secara bersama-sama. Kriteria keputusan yang digunakan adalah apabila nilai Sig. $F$ lebih besar dari 0,05 diartikan tidak terdapat perbedaan yang signifikan antara ketiga indikator yang dianalisis dalam mengevaluasi return saham; sebaliknya, apabila nilai Sig. F lebih kecil dari 0,05 berarti terdapat perbedaan yang signifikan di antara ketiga indikator yang dianalisis dalam mengevaluasi return saham (Suharyadi \& Purwanto, 2009).

Terakhir, dilakukan uji independent sample t-test. Pengujian ini digunakan untuk membandingkan rata-rata dua grup data. Secara khusus, uji beda ini digunakan untuk mengetahui perbedaan return saham dari penggunaan indikator-indikator Bollinger Band, Parabolic SAR, serta Stochastic Oscillator. Kriteria pengambilan keputusan adalah apabila nilai Sig. $t$ lebih kecil dari 0,05 berarti terdapat perbedaan return saham menggunakan ketiga indikator tersebut; sebaliknya, apabila nilai Sig. $t$ lebih besar dari 0,05 berarti tidak terdapat perbedaan return saham menggunakan ketiga indikator tersebut (Suharyadi \& Purwanto, 2009).

\section{HASIL ANALISIS}

\section{Perbandingan Hasil Return Saham}

Pada tahap pertama, dilakukan analisis perbandingan atas nilai-nilai return saham yang diperoleh melalui ketiga indikator terkait pergerakan harga saham sektor infrastruktur, utilitas, dan transportasi periode 2017-2019. Data return saham yang diperoleh ditunjukkan dalam Tabel 2; dimana BB adalah indikator Bollinger Band, PSAR adalah indikator Parabolic SAR, dan SO adalah indikator Stochastic Oscillator. 
Tabel 2. Perbandingan Return Saham dari Tiga Indikator Periode 2017-2019

\begin{tabular}{clrcr}
\hline \multirow{2}{*}{ No. Kode Saham } & & \multicolumn{3}{c}{ Return Saham $(\%)$} \\
\cline { 3 - 5 } & & BB & PSAR & SO \\
\hline 1 & ASSA & 39,81 & 156,81 & 137,20 \\
2 & BIRD & 18,42 & 82,92 & $-7,77$ \\
3 & BULL & 33,07 & $-38,93$ & 44,40 \\
4 & EXCL & 37,98 & 12,22 & 53,28 \\
5 & GIAA & 10,15 & 27,71 & 27,03 \\
6 & JSMR & 4,96 & 9,86 & 15,03 \\
7 & MBSS & 99,97 & 44,18 & 87,31 \\
8 & PGAS & 49,14 & 7,04 & $-28,99$ \\
9 & POWR & $-10,78$ & $-8,30$ & 14,23 \\
10 & RAJA & $-5,26$ & 35,36 & 108,90 \\
11 & SMDR & 1,53 & 66,29 & 76,99 \\
12 & SOCI & $-20,86$ & 18,86 & 10,38 \\
13 & TBIG & 0,21 & 42,76 & 9,53 \\
14 & TLKM & 41,21 & $-25,19$ & 27,89 \\
\hline & Return Rata-Rata & 21,36 & 30,83 & 41,10 \\
\hline
\end{tabular}

Sumber: Data sekunder (diolah), 2020.

Berdasarkan Tabel 2 diperoleh return saham yang dihasilkan melalui indikator Bollinger Band dalam pergerakan harga saham di sektor infrastruktur, utilitas, dan transportasi. Data menunjukkan terdapat 11 perusahaan memperoleh return saham bernilai positif selama periode 2017 sampai 2019, yaitu ASSA (39,81\%), BIRD (18,42\%), BULL (33,07\%), EXCL (37,98\%), GIAA (10,15\%), JSMR (4,96\%), MBSS (99,97\%), PGAS $(49,14 \%)$, SMDR $(1,53 \%)$, TBIG $(0,21 \%)$, dan TLKM $(41,21 \%)$. Sementara itu, diperoleh tiga perusahaan mengalami return saham bernilai negatif selama periode penelitian, yaitu POWR $(-10,78 \%)$, RAJA $(-5,26 \%)$, dan SOCI $(-20,86 \%)$.

Dengan demikian, hasil analisis menggunakan indikator Bollinger Band menunjukkan nilai return saham terbesar dicapai oleh MBSS sebesar 99,97\%, sementara nilai return saham terendah diperoleh SOCI sebesar $-20,86$ persen. Rata- rata return yang dihasilkan menggunakan indikator ini sebesar 21,36 persen.

Berikutnya, nilai return saham yang dihasilkan melalui indikator Parabolic SAR berdasarkan Tabel 2 dalam pergerakan harga saham di sektor infrastruktur, utilitas, dan transportasi juga menunjukkan 11 perusahaan mengalam return saham bernilai positif naamun dengan kode saham yang berbeda. Perusahaan-perusahaan itu adalah ASSA (156,81\%), BIRD (82,92\%), EXCL (12,22\%), GIAA $(27,71 \%), \quad$ JSMR $(9,86 \%)$, MBSS $(44,18 \%)$, PGAS $(7,04 \%)$, RAJA $(35,36 \%)$, SMDR $(66,29 \%)$, SOCI $(18,86 \%)$, dan TBIG $(42,76 \%)$. Sementara itu, perusahaanperusahaan yang mengalami return saham bernilai negatif adalah BULL $(-38,93 \%)$, POWR (-8,30\%), dan TLKM (-25,19\%).

Berdasarkan hasil analisis menggunakan indikator Parabolic SAR terlihat bahwa nilai return saham terbesar dicapai oleh ASSA sebesar $156,81 \%$, sementara nilai return saham terendah diperoleh BULL sebesar 
$-38,93$ persen. Nilai rata-rata return yang dihasilkan menggunakan indikator ini sebesar 30,83 persen.

Indikator ketiga yang diperbandingkan yaitu Stochastic Oscillator memberikan data return saham berlandaskan pergerakan harga saham di sektor infrastruktur, utilitas, dan transportasi selama periode 2017-2019. Tabel 2 menunjukkan bahwa berdasarkan indikator ini terdapat 12 perusahaan yang memperoleh return saham yang bernilai positif, yaitu ASSA (137,20\%), BULL (44,40\%), EXCL $(53,28 \%)$, GIAA $(27,03 \%)$, JSMR $(15,03 \%)$, MBSS (87,31\%), POWR (14,23\%), RAJA (108,9\%), SMDR $(76,99 \%)$, SOCI $(10,38 \%)$, TBIG $(9,53 \%)$, dan TLKM $(27,89 \%)$. Selain itu, indikator ini menyatakan adanya dua perusahaan yang mengalami return saham yang bernilai negatif, yaitu BIRD $(-7,77 \%)$ serta PGAS $(-28,99 \%)$.

Dengan demikian, hasil analisis menggunakan indikator Stochastic Oscillator menunjukkan nilai return saham terbesar dicapai ASSA sebesar 137,20\%, sementara nilai return saham terendah diperoleh PGAS sebesar $-28,99$ persen. Rata-rata return yang dihasilkan menggunakan indikator ini sebesar 41,10 persen.

\section{Hasil Uji Normalitas dan ANOVA}

Hasil uji normalitas menggunakan metode Shapiro-Wilk ditunjukkan dalam Tabel 3. Hasil pengujian menyatakan nilai Asymp. Sig. (2-tailed) baik untuk indikator Bollinger Band (0,201), indikator Parabolic SAR $(0,234)$ maupun indikator Stochastic Oscillator $(0,520)$ adalah lebih besar dari 0,05 . Dengan demikian dapat diartikan bahwa semua variabel merupakan data berdistribusi normal atau signifikan.

Tabel 4 menunjukkan hasil analisis ANOVA bahwa $p$-value dari uji $\mathrm{F}$ diperoleh sebesar 0,486. Dengan demikian, karena nilai Sig. $F$ lebih besar dari 0,05 maka dinyatakan tidak terdapat perbedaan yang signifikan di antara ketiga indikator yang dianalisis dalam penelitian ini untuk mengevaluasi return saham perusahaan di sektor infrastruktur, utilitas, dan transportasi yang terdaftar pada Bursa Efek Indonesia periode 2017-2019.

\section{Uji Independent Sample T-test}

Pada bagian ditunjukkan hasil analisis perbandingan return saham di antara ketiga indikator yang dievaluasi dalam penelitian ini, yaitu Bollinger Band, Parabolic SAR, serta Stochastic Oscillator.

\section{Tabel 3. Hasil Uji Normalitas}

\begin{tabular}{clcc}
\hline \multirow{2}{*}{ No } & & \multicolumn{2}{c}{ Shapiro-Wilk } \\
\cline { 3 - 4 } & & Statistic & Sig. \\
\hline 1 & Bollinger Band & 0,917 & 0,201 \\
2 & Parabolic SAR & 0,922 & 0,234 \\
3 & Stochastic Oscillator & 0,947 & 0,520 \\
\hline
\end{tabular}

Sumber: Data sekunder (diolah), 2020.

\section{Tabel 4. Hasil ANOVA}

\begin{tabular}{cccc}
\hline No & Variabel & F-hitung & Sig. (2-tailed) \\
\hline 1 & Return Saham BB, PSAR, SO & 0,734 & 0,486 \\
\hline
\end{tabular}

Sumber: Data sekunder (diolah), 2020. 
Tabel 5. Hasil Uji Independent Sample t-test

\begin{tabular}{cccc}
\hline No & Variabel & t-hitung & Sig.(2-tailed) \\
\hline 1 & Return Saham Bollinger - Parabolic & $-0,608$ & 0,548 \\
2 & Return Saham Bollinger - Stochastic & $-1,311$ & 0,201 \\
3 & Return Saham Parabolic - Stochastic & $-0,567$ & 0,575 \\
\hline
\end{tabular}

Sumber: Data sekunder (diolah), 2020.

Tabel 5 menunjukkan nilai t-hitung untuk perbandingan return saham antara indikator-indikator Bollinger dan Parabolic sebesar -0,608; antara Bollinger dan Parabolic sebesar -1,311; dan, antara Parabolic dan Stochastic sebesar -0,567. Karena nilai Sig.t (2-tailed) untuk ketiga model komparasi itu lebih besar dari 0,05 maka dinyatakan secara statistik bahwa tidak terdapat perbedaan yang signifikan dari ketiga indikator tersebut dalam menghasilkan return saham.

\section{Pembahasan}

Penelitian ini melakukan perbandingan antara indikator-indikator Bollinger Band, Parabolic SAR, dan Stochastic Oscillator untuk menghasilkan return saham. Studi pada 14 sampel perusahaan dalam sektor infrastruktur, utilitas, dan transportasi untuk periode 2017-2019. Berdasarkan hasil analisis data diperoleh tidak terdapat perbedaan yang signifikan dari ketiga indikator tersebut dalam menghasilkan return saham. Karenanya, indikator-indikator Bollinger Band, Parabolic SAR, dan Stochastic Oscillator dinyatakan sama-sama mampu memberi jawaban berkaitan dengan waktu yang terbaik dalam membeli ataupun menjual saham untuk mendapatkan return saham yang optimal.

Terdapat beberapa penelitian terdahulu yang mendukung mengenai penggunaan indikator Bollinger Band, Parabolic SAR serta Stochastic Oscillator. Frankandinata \& Cahyadi (2014) menyatakan bahwa indikator Bollinger Bands dapat dipertimbangkan untuk analisis pergerakan harga saham AALI; Marli
\& Deccasari (2014) menyatakan bahwa indikator Bollinger Band merupakan indikator volatilitas yang bisa dipakai sebagai indikator action untuk mengambil keputusan investasi di dalam transaksi short time perdagangan saham; serta, Srichawla \& Romprasert (2017) yang menyatakan bahwa indikator Parabolic SAR merupakan indikator konfirmasi yang paling menguntungkan pada saham di Bursa Thailand.

Selain itu, Sulthon et al. (2018) menemukan hasil bahwa Parabolic SAR merupakan indikator tambahan untuk mengidentifikasi tren ketika buy atau sell. Prabatha (2012) menyatakan indikator Stochastic Oscillator secara signifikan bisa memperoleh profit bagi investor pada saham-saham JII; M'ng \& Mehralizadeh (2016) yang meneliti mengenai Bollinger Band dan Stochastic Oscillator di pasar berjangka; serta, Prasetyo et al. (2019) memperoleh temuan bahwa Stochastic Oscillator bisa digunakan sebagai sinyal untuk mendapatkan keuntungan yang optimal dan syar'i pada saham yang terdaftar di Jakarta Islamic Index (JII).

Di sisi lain, terdapat sejumlah penelitian terdahulu yang menemukan hasil yang bertolak belakang dengan temuan penelitian ini. Suryawan \& Bagiarta (2017) memperoleh hasil penelitian yang menyatakan bahwa indikator Bollinger Band masih belum optimal pada pair AUD/USD dan EUR/USD; How et al. (2015) memperoleh temuan bahwa indikator Parabolic SAR tidak mampu memprediksi dengan tepat harga. Demikian juga, Suryawan (2016) memperoleh hasil riset 
yang menyatakan bahwa indikator Stochasic belum mampu memberikan sinyal tentang keuntungan secara konsisten di forex.

Walaupun antara ketiga indikator yang dianalisis dalam penelitian ini dinyatakan tidak memiliki perbedaan secara statistik, namun dinilai memiliki perbedaan dalam segi persentase return yang dihasilkan. Seperti ditunjukkan dalam Tabel 2, nilai return rata-rata untuk indikator Bollinger Band sebesar 21,36\%; indikator Parabolic SAR sebesar 30,83\%; dan, indikator Stochastic Oscillator sebesar 41,10\%. Perbedaan besar kecilnya rata-rata return itu didasari dari masingmasing indikator yang dianalisis. Bollinger Band dapat bekerja dengan nilai volatilitasnya (Hafizah et al., 2019). Untuk volatilitas tinggi, maka jarak antara kedua band akan melebar. Hal ini terjadi ketika berubah dari kondisi pasar sideways menjadi kondisi pasar trending. Sebaliknya, volatilitas pasar yang rendah terlihat pada jarak kedua band yang menyempit, hal ini biasa terjadi ketika ada perubahan dari kondisi pasar trending ke kondisi pasar yang sideways (Pramudya \& Ichsani, 2020).

Parabolic SAR memiliki sifat Trend Following, yaitu menginformasikan mengenai trending-nya suatu pasar dan mengindikasikan pembalikan suatu harga. Apabila terdapat candlestick melampaui titik Parabolic SAR secara berlawanan dengan trend, maka posisi yang terbuka untuk segera ditutup (Basrowi et al., 2020). Sementara itu, indikator Stochastic Oscillator berpusat pada oscillator dengan kisaran 0\%-100\% dan menampilkan dua garis yaitu $\% \mathrm{~K}$ dan \%D. Apabila garis \%K memotong garis \% keatas dengan rentang 0\%-20\% mengindikasikan sinyal beli; namun apabila garis \% memotong garis $\% \mathrm{~K}$ ke bawah dengan rentang 80\%-100\% maka mengindikasikan sinyal untuk keputusan jual (Tobing et al., 2019).
Implikasi dari penelitian ini diharapkan mampu dijadikan bahan pertimbangan bagi investor maupun manajer investasi dalam pengambilan keputusan investasi untuk menganalisa maupun menentukan indikator yang tepat dalam membeli dan menjual suatu saham sehingga meminimalkan resiko serta memaksimalkan return yang ingin diraih.

\section{SIMPULAN}

Berdasarkan hasil penelitian yang diperoleh menggunakan uji independent sampel t-test yaitu membandingkan rata-rata dua grup data, didapatkan kesimpulan bahwa tidak terdapat perbedaan yang signifikan pada perusahaan sektor infrastruktur, utilitas, dan transportasi selama periode 2017-2019. Dengan demikiaan, ketiga indikator Bollinger Band, Parabolic SAR, dan Stochastic Oscillator dapat dijadikan pedoman dalam menentukan keputusan jual atau beli atas saham untuk mendapatkan return saham yang optimal pada perusahaan-perusahaan yang terdaftar di BEI, khususnya di dalam sektor infrastruktur, utilitas, dan transportasi.

Penelitian ini terbatas hanya meneliti perbandingan dari masing-masing indikator dari analisis teknikal. Karenanya penelitian berikutnya disarankan untuk melakukan kombinasi atas metode indikator yang ada ataupun menambah metode indikator lain seperti MACD dan RSI, untuk memperoleh hasil yang lebih akurat dalam menghasilkan return saham yang optimal. Bagi penelitian selanjutnya juga disarankan untuk menambah time frame yang lebih panjang dibandingkan yang dilakukan pada penelitian ini, sehingga penelitian selanjutnya tersebut diekspektasikan memiliki keakurasian yang lebih baik lagi. Selain itu, penelitian berikutnya juga dapat menggunakan jenis-jenis indeks lain yang ada di Bursa Efek Indonesia. 


\section{REFERENSI}

Artanti, A. A. (2019). BEI catat jumlah investor pasar modal meningkat 53\%. Retrieved from https://www.medcom. id/ekonomi/bursa/ybJVw5ab-2019-beicatat-jumlah-investor-pasar-modalmeningkat-53.

Basrowi, Fauzi, \& Utami, P. (2020). Apakah memilih saham daftar efek syariah indonesia dengan analisis teknikal akan menguntungkan? AL-INFAQ: Jurnal Ekonomi Islam, 11(1), 39-59. doi: 10.32507/ajei.v11i1.555.

Frankandinata, \& Cahyadi, Y. (2014). Analisis keakuratan indikator Bollinger Bands terhadap pergerakan harga saham: Studi kasus pada saham PT. Astra Agro Lestari Tbk. Binus Business Review, 5(1), 112-122. doi: 10.21512/ bbr.v5i1.1201.

Hafizah, N., Noviani, E., \& Perdana, H. (2019). Analisis teknikal saham LQ-45 menggunakan indikator Bollinger Bands. Buletin Ilmiah Math. Stat. Dan Terapannya (Bimaster), 08(4), 943950. Retrieved from: https://jurnal. untan.ac.id/index.php/jbmstr/article/vie w/36653.

Hendarto, K. (2005). Belajar trading: Pahami Trading sebelum anda mulai. Penerbit Andi.

How, S., Wendy, \& Mardiansyah, R. (2015). Penggunaan alat analisis teknikal Candlestick dan Parabolic Sar dalam perdagangan berjangka komoditas emas: Studi eksperimental. EJME: Equator Journal of Management and Entrepreneurship, 3(2). Retrieved from https://jurnal.untan.ac.id/index.php/jmd b/article/view/8652.

M’Ng, J. C. P., \& Mehralizadeh, M. (2016). Forecasting east asian indices futures via a novel hybrid of wavelet-PCA denoising and artificial neural network models. PLOS ONE, 11(6), 1-29. doi: 10.1371/journal.pone.0156338.

Marli, \& Deccasari, D. D. (2014). Penerapan analisis teknikal dengan metode Bollinger sebagai salah satu indikator dalam transaksi short time perdagangan saham. Jurnal Dinamika DotCom, 5(1), 64-79. Retrieved from http://www. semenindonesiarun.com/index.php?jour nal $=$ DINAMIKA\&page $=$ article $\& o p=v i$ ew\&path $\% 5 \mathrm{~B} \% 5 \mathrm{D}=75$.

Ong, E. (2016). Technical analysis for mega profit. PT. Gramedia Pustaka Utama.

Prabhata, A. (2012). Efektifitas penggunaan analisis teknikal Stochastic Oscillator dan Moving Average ConvergenceDivergence (MACD) pada perdagangan saham-saham Jakarta Islamic Index (JII) di bursa efek Indonesia. Sinergi, 13(1), 1-14. doi: 10.20885/sinergi. vol13.iss1.art1.

Pramudya, R., \& Ichsani, S. (2020). Efficiency of technical analysis for the stock trading. International Journal of Finance \& Banking Studies, 9(1), 5867. doi: 10.20525/ijfbs.v9i1.666.

Prasetyo, P., Nurlaely, \& Subagyo, H. (2019). Analisis komparatif penggunaan metode Stochastic, Moving Average dan MACD dalam mendapatkan keuntungan optimal dan syar'i (Study pada Jakarta Islamic Index 2016 2018). JIMEK: Jurnal Ilmiah Mahasiswa Ekonomi, 2(1), 52-68. doi: 10.30737/jimek.v2i1.414.

Rahardjo, S. (2006). Kiat membangun aset kekayaan. PT. Elex Media Komputindo

Samsul, M. (2006). Pasar modal \& manajemen portofolio. Erlangga.

Santoso, S. (2015). SPSS 20: Pengolahan data statistik di era informasi. PT. Elex Media Komputindo.

Srichawla, S., \& Romprasert, S. (2017). The effectiveness of confirming indicators: A case study of stocks in Thailand Shivathep. The Journal of Risk Management and Insurance, 21(1), 4160. Retrieved from https://jrmi.au.edu/ index.php/jrmi/article/view/156.

Sugiyono. (2016). Metode penelitian kuantitatif, kualitatif, dan $R \& D$. CV. Alfabeta. 
Suharyadi, \& Purwanto. (2009). Statistika untuk ekonomi dan keuangan modern. Salemba Empat.

Sulthon, M. L., Prasetijo, A. B., \& Somantri, M. (2018). Pendeteksi sinyal jual / beli saham dengan Fuzzy Rule-based Evidential Reasoning dan C-means Clustering. JNTETI, 7(3), 287-296. doi: 10.22146/jnteti.v7i3.437.

Sunariyah. (2006). Pengantar pengetahuan pasar modal. Unit Penerbit dan Percetakan STIM YKPN.

Suryani, \& Hendryadi. (2016). Metode riset kuantitatif: Teori dan aplikasi pada penelitian bidang manaejemen dan ekonomi islam. Pranadamedia Group.

Suryawan, I K. D. (2016). Analisa pergerakan market dengan kombinasi indikator Stochastic dan Linier Weighted Moving Average. Journal JOINS Udinus, 1(2), 92-100. doi: 10.33633/joins.v1i2.1301.
Suryawan, I K. D., \& Bagiarta, I. G. N. N. (2017). Expert advisor dengan strategi Moving Average, RSI dan Bolinger Band. Jurnal Sistem dan Informatika, 11(2), 1-9. Retrieved from https://jsi. stikom-bali.ac.id/index.php/jsi/article/ view/106.

Tandelilin, E. (2001). Analisis investasi dan manajemen portofolio. BPFEYogyakarta.

Tobing, Y. L. L., Syafrida, I., \& Agha, R. Z. (2019). Anomali sinyal Stochastic dan Fibonacci terhadap pergerakan saham di Bursa Efek Indonesia (BEI) dengan metode arus dana investor asing. Account, 6(1), 992-1001. doi: 10. 32722/acc.v6i1.1382. 